This work is licensed under a Creative Commons Attribution 4.0 International License.

Ovaj rad dostupan je za upotrebu pod licencom Creative Commons Imenovanje 4.0 međunarodna.

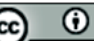

\section{Šimo ŠOKČEVIĆ}

Catholic Faculty of Theology in Đakovo

Josip Juraj Strossmayer University of Osijek

Petra Preradovića 17

HR - 31400 Đakovo

simo.sokcevic@djkbf.hr

\section{Tihomir ŽıVIĆ}

Faculty of Agrobiotechnical Sciences Osijek Josip Juraj Strossmayer University of Osijek

Vladimira Preloga 1

HR - 31000 Osijek

tihomir.zivic@fazos.hr
UDK 272-732.2 Newman, J.

27-722 Strossmayer, J. J.

322

DOI: https://doi.org/10.29162/ANAFORA.v8i1.6

Izvorni znanstveni članak

Original Research Article

Primljeno 16. rujna 2020.

Received: 16 September 2020

Prihvaćeno 16. veljače 2021.

Accepted: 16 February 2021

\title{
NEWMAN AND STROSSMAYER ON THE RELATIONSHIP BETWEEN THE CHURCH AND THE STATE (II)
}

\begin{abstract}
The cooperation between the Catholic Church and the State is a necessity and an imperative that was addressed by two important thinkers of the 19th century, John Henry Newman and Josip Juraj Strossmayer, and the models that actually trace back to their reflections are existent even nowadays.

In the second part of a textological and theological analysis of Newman's and Strossmayer's understanding of the relationship between the Church and the State, our objective is to explore how much Newman's and Strossmayer's deliberations may be useful in the formulation of the bases on which a good relationship between the Catholic Church and the State should be built. We have seen that comprehension and concord are the fundamental imperatives of that relationship, as well as of the contemporary models that analyze it. The modern obstacles to this relationship have the identical roots, findable in negative liberalism and repaganization.
\end{abstract}


On the trail of Newman and Strossmayer, we conclude that an anthropological reform primarily taking hold of the human heart is necessary today. Therefore, such a reform has to realize that the life in accordance with one's own conscience, in the truth, is more valuable than all the utopian lies and deceptions that formulate the socioeconomic relations and personal life.

Keywords: John Henry Newman, Josip Juraj Strossmayer, Catholic Church, relation, anthropological reform

\section{Introduction}

In the previous article on the relationship between the Catholic Church and the State from Newman's and Strossmayer's perspective, we have mentioned the significance of the theological dogma of incarnation of the Divine Logos in Jesus of Nazareth and have additionally addressed the importance of a well-rounded knowledge of patristics, given that the Church Fathers were historically most proximate to the event. Still, the incarnation is also significant because it can, as a subject of deliberation, be related to a modern, liberal idea of tolerance, which is very rarely done by the authors. An exception thereto is Stjepan Kušar's article "Inkarnacija, tolerancija i djelovanje Crkve" in the second volume of the 1999 book Liberalizam i katolicizam u Hrvatskoj, edited by Hans-Georg Fleck (295-332).

In that sense, it is usually hypothesized that that incarnation excludes tolerance and vice versa. It is opined, viz., that "a dogma on incarnation forms the basis for the comprehension of Christianity as an absolute religion, and that comprehension is subsequently interpreted as a possible origin of intolerance toward others" ("dogma o inkarnaciji tvori temelj shvaćanja kršćanstva kao apsolutne religije, a onda se to shvaćanje tumači kao mogući izvor nesnošljivosti prema drugima"; Kušar 295). ${ }^{1}$ On the other hand, it is known that "an idea of religious tolerance has been slowly established as the only exit from the religious wars that have marked the European modern age" ("[se] ideja religijske tolerancije polako uspostavila kao jedini izlaz iz religijskih ratova, koji su obilježili rano europsko novovjekovlje"; Kušar 295). By these two notions, as well as by the relationship between the Church and the State, Strossmayer and Newman, like some contemporary authors, demonstrate that it is possible to cogitate jointly, 
i.e., the incarnation does not only include tolerance, but it also "opens an avenue to love through it, which culminates in laying down the lives for others, whoever they might be" ("otvara put preko nje u ljubav, koja kulminira u polaganju života za druge, koji god i kakvi god oni bili”; Kušar 295). To that effect, it is completely justified to ponder the relationship of the Catholic Church and the State, of course without pretensions that a religious transcendency be a legitimation of any system or a nation type (Kušar 318). Naturally, it is not ultimately possible to precisely separate a domain of religion from that of policy, since these two dimensions cannot coexist without contingency and mutual permeation, for "the same people are both the believers and the citizens of a state (which, of course, does not mean that all the citizens of a state are simultaneously believers)" ("isti su ljudi i vjernici i građani države [što dakako ne znači da su svi građani države ujedno i vjernici]"; Kušar 319).

In addition to a discourse on incarnation, we have seen in the previous article that the power of the Church resides upon its consistency, authenticity, veracity, and liberty. However, we would say that the power of the State itself lies exactly in these principles, too, since a State Authority that is not authentic, that is not in the truth, which is a utopia, is doomed to failure sooner or later. As the individuals within the Church may be peccable, so may the representatives of a State Authority err, i.e., they may be separated from a mission of their own, which is to act for the common good of their own State and society. Yet, the peccable individuals, and even the "impieties of structures" ("grijesi struktura"; Šagi 282-89), cannot destroy the essence of the mission of a State Authority and the Church, so Strossmayer and Newman keep emphasizing that the State Authority deserves respect and obedience in conscience, but, naturally, up to an extent to which the State laws and regulations do not imperil God's declared truth.

That stance was specially expounded by Strossmayer in the 1886 Lenten circular, where he speaks about the genesis, nature, and purpose of the State and of the Church (Čečatka 36; Strossmayer 42). He speaks about their mutual relationship and stresses that God has created the human being as a social one, as "it cannot adequately develop and elevate either its intellect, its heart, or any other ability, let alone obtain any higher intent, sequestrated and without company" (“[čovjek] osamljen i bez društva niti um svoj, niti srce svoje, niti ijednu drugu moć svoju kako valja razviti i oplemeniti, niti ikoju višu svrhu polučiti ne može”; Strossmayer 43). He accentuates that both an individual and the human society are from God and by God (Strossmayer 44). In this connection, it is important 
to bear in mind that the Church does not oppose to the State by its law and demeanor. At Pope's wake, Strossmayer demonstrates that any Authority is from God and that the laws which "would be adequate to the common good while resisting to the holy faith" cannot exist ("[bi] odgovarali općem dobru, a koji bi se opirali svetoj vjeri"; 44). Jesus has said Himself: "Pay Caesar what belongs to Caesar-and God what belongs to God" (New Jerusalem Bible, Mark 12.17). That sentence evinces the autonomy and independence of the Church and of the ecclesiastical Authority, as well as that of the state and the State Authority, very clearly. The separation of the Church from the State in the history of Western democracies has been manifested as the "best solution," and we may say that Strossmayer is exactly on this trail.

In this paper, however, we have concentrated on a presentation of the relationship between the Church and the State in Newman and Strossmayer while leaving room for some future research, particularly that of Strossmayer's opinions in a context of the aforementioned separation within the history of Western democracy. Hereby, we would like to point out the fact that the Church has fought hard against that "best solution" throughout history, because the separation deprives it of an external power, which it reluctantly lets out of its hands. Having acquiesced to the brachium seculare, namely, the Church had to subordinate the universal to the particular, i.e., the Kingdom of God to the Kingdom of Man. Thus, the Church invites the citizens to obedience to the State and to State law, and it is by nature and vocation a pledge of peace, love, and concord (Strossmayer 531).

It does not advocate a specific State system by its sacred doctrine, but when it tutors that any Authority is from God, it actually desires to consecrate the State Authority in its very origin and to rely on the very God, "it desires to dignify the human obedience and transform it into an obedience to God; yet, thereby, it very seriously remonstrates the State Authority not to only rely on the naked truth in the use of its power, for it can never reach the heart and consciousness" (“želi posluh čovječji oplemeniti i u posluh prema Bogu pretvoriti; ali ona time i državnu vlast ozbiljno opominje da se u uporabi svoje moći nikada ne oslanja samo na golu silu, koja nikada do srca i svijesti ne može doprijeti"; Strossmayer 530). A modern, liberal democratic State lives on certain preconditions that it does not create and cannot guarantee itself. It may exist as "liberal" if the liberty that it guarantees to its citizens be regulated internally, i.e., from the moral substance of an individual and from the citizens' value consensus. Nonetheless, 
"a democratic state cannot guarantee a moral substance and a value consensus alone, imposing them by the means of a legal coercion and authoritarian regulations" as it is frequently the case nowadays ("moralnu supstanciju i vrijednosni konsenzus demokratska država ne može sama jamčiti namećući ih preko sredstava zakonske prisile i autoritativnih propisa"; Kušar 319-20).

In that regard, it is especially relevant for Strossmayer, inter alia, that the public Authority and the State take care of public worship. On the trail of the aforementioned facts, it is also logical, for a modern liberal State should keep and vouch an open and free access to transcendency, which is religiously determined. Thereby, the State does nor prescribe a religion to the citizens or determine transcendency substantively in any way. The State, in that sense, should be a "warranting instance of a free access to transcendency" ("jamstvena instanca slobodnoga pristupa transcendenciji”; Kušar 321) because the human soul aspires to immortality, and a human being, a believer, has a right to demand that nothing obstructs this human aspiration in that context. What is more, "the society is obliged to do so by its internal being and by its divine origin, and all the state and societal purposes are exalted and consecrated thereby" ("društvo je to unutarnjim svojim bićem i božanstvenim svojim izvorom obvezano činiti, a time se i sve državne i društvene svrhe uzvisuju i posvećuju”; Kušar 57).

\section{Understanding and Concord between the Church and the State}

Strossmayer punctuates furthermore that, though each Authority is from God, the people decide on its external form, as it is mentioned (Kušar 52). It is especially significant to the Church that the people know that the public Authority is from God and by God. That implies that, as such, it is not for the benefit of an individual or a small-sized group but for the common good. Also, Strossmayer underscores that if "the state is indirectly from God and by God, the Church is directly from God and by God Jesus Christ, ... and each of these two Authorities is free, be it also independent, in its jurisdiction, but each of them is also simultaneously referred to mutual devotion, accord, and communication" ("država [je] posredno od Boga i po Bogu, Crkva je neposredno od Boga i po Bogu Isusu Kristu ... i svaka je od tih dviju vlasti u svojoj nadležnosti slobodna, doduše i neovisna, ali je ujedno i svaka upućena na međusobno štovanje, slogu i sporazumijevanje; qtd. in Kušar 52). When it comes to devotion, the Church, originating in God and being stipulated by Him, manifests devotion to the State Authority, yielding place to the State laws in human conscience and re- 
quiring a believer to comply with a State law not only because of apprehension, but because of God and conscience. Nevertheless, the State Authority is also expected to reciprocally protect the Church liberty and to enable the citizens to be aware of the noble and decent intentions of this world, to "promote the obtainment of the eternal purpose and the ultimate commitment of each citizen, a believer" ("promiče i postignuće vječne svrhe i posljednjega opredjeljenja svakog građanina, vjernika"; Kušar 68). To put it differently, we see that Newman also recognized the significance of a sound relationship between an individual's conscience and the Authorities, both the ecclesiastical and the State ones.

Thus, discernment and harmony are something enjoined by God to both the Church and to the State. "One and the same human being is from God and by God both as a citizen and as a believer. Both the State and the Church are from God and by God. God may not contradict Himself, so there may be no internal opposition in the orientation of the Church and of the State" ("Jedan te isti čovjek i kao građanin i kao vjernik od Boga i po Bogu je. I Država i Crkva su od Boga i po Bogu. Bog ne može sam sebi protusloviti, tako da u opredjeljenju Crkve i Države ne može biti nutarnje opreke"; Kušar 68). The State Authority should be especially cautious not to promulgate the laws opposite to the divine law, for it would be a misfortune for the State itself. In that regard, Strossmayer invokes the Pope, who points out that this visible world is in fact an image and likeness of the admirable accord and unity in which God's mercy and benevolence echo in a special way and the goals of this world are being fulfilled. The Holy Father wishes to say that it is the same in God.

Besides, the conscientious individuals are the fundament of economy, politics, and of a healthy society. A Christian has to be aware of his or her civic duties, the first one being that he or she is unconditionally obedient to the Church. Strossmayer excellently speaks about that obedience, claiming that the compliance should be unconditional, for "if the Church is sacred, a living entity and the Body of Christ, and if it stands, acts, and enacts the laws under a special protection and special inspiration of the Holy Spirit, ... then it is entirely natural and unavoidable that anyone should listen to the Church and obey it, like Jesus and the Holy Spirit" ("ako je sveta Crkva, biće od bića Isusova, i ako pod osobitom zaštitom i osobitim nadahnućem Duha Svetoga stoji, djeluje i zakone obnaša, ... onda je posve naravno i neizbježno, da trebamo svi Crkvu slušati i njoj se, kao i Isusu i Duhu Svetomu, pokoriti”; qtd. in Kušar 516). This is exactly so up to the demise, since all of us are redeemed via crucifix by the sacrament 
of humility and obedience, and we are equally saved by the powers of humility and obedience, which we owe to Jesus Christ and to the sacred Spirit of His (Kušar 516). For Strossmayer, a Christian is required to love his or her country, but even more so the Church. Of course, a public Authority is, says Strossmayer, something hallow, for a Christian recognizes in it "a reflection and an image of God's majesty" ("odsjaj i sliku veličanstva Božjega”; qtd. in Kušar 516), even if the Authority is exercised by an unworthy incumbent. It is righteous and it is a duty of each Christian to respect the laws, not because of a force or threats but because of conscience, for "God did not give us a spirit of timidity, but the Spirit of power and love and self-control” (2 Tim 1.7).

Still, if the laws of the State contravene God's laws, if they are inequitable when it comes to the Church, if they controvert the religious duties or offend Christ's reputation in the Pope, then resistance is a duty, then the obedience is a $\sin$ (Kušar 519). Strossmayer propounds that a human being in the society and in the state is invited "to possibly multiply both a social, psychical, and physical property by his or her work, by his or her assiduity, by his or her goodness and by his or her sacrifice, since that opulence of social goods is not only a benediction, honor, and pride of integrity, but it is also significant to each individual" ("svojim radom, svojom revnošću, svojim dobrom i svojom požrtvovnošću društveni imetak, i duševni i tjelesni, po mogućnosti umnažati, jer je to izobilje dobara društvenih, ne samo blagoslov, čast i ponos cjelokupnosti, nego je također i svakom pojedincu važno"; qtd. in Kušar 96). In this connection, any inertia and indolence are condemned when transferred to the State, to the society whose citizen the person is (Kušar 46-47).

To that effect, a great responsibility lies with the clergymen, who are invited to sanctity as the laical believers. However, Strossmayer especially emphasizes the relevance of the clergymen, whose first and the most important task is to officiate their priesthood duties punctually and consciously. Strossmayer points out that "in vain is a priest, God knows how devout and diligent he might be, if he does not perform his clerical duty sacredly and wholeheartedly. Such a one holds no value, he is a sadness, a regret, and a taunt to the Church, but he is of no use to the state either" ("uzalud svećenik, bogznakako inače revan i radišan bio, ako ne obnaša svoju svećeničku dužnost sveto i zdušno; takav ništa ne vrijedi, tuga je, žalost i ruglo Crkvi, ali nije ni državi na korist”; qtd. in Kušar 97). A pettifogging minster of the kind spreads darkness by his lifestyle all around, and he is "the death and perdition for many" (positus in ruinam multorum) (Kušar 
97). Priesthood is the most sacred, the finest, and the most Salvific, since Christianity is the soul, the life, the light, and the glory to the State and to the people, so the clergymen are the advocates, defenders, and promotors of that life and that glory by virtue of their acquirement, doctrine, and example. On the other hand, this is also a derivation of an immense responsibility that the clergymen have by this ministry of theirs. Therefore, Strossmayer considers that "the greatest gift that God could donate from His heart to the Chosen People are its good priests and adorable prophets" ("najveći dar koji je Bog mogao iz svojega srca dati izabranome narodu jesu bili dobri svećenici i divni proroci njegovi”; qtd. in Kušar 97).

Strossmayer wishes to say that the State has to be aware that it is not the single source of the right and liberty, and exceptional damage is certainly inflicted upon the State itself if the State laws are in opposition to the divine laws. E.g., debauchery within a marriage and family is directly translated into society and has catastrophical consequences. Still, Strossmayer notes yet another very topical problem: when the Church speaks about it publicly, it is then "stoned and muckraked and accused of disturbing peace and amity" ("[onda se na nju] kamenom i blatom nabacuje te joj se spočitava da remeti mir i slogu”; qtd. in Kušar 75). It is indubitable that the Church should support the State, but the State should support the Church, too. Nonetheless, Strossmayer realizes the relationship of the State toward the Church is not such, that intolerance is increasingly present in the State, which he perceives as a sign of the new paganism (Kušar 535). Presently, this new paganism is especially pronounced, and we will elaborate it later in the text in more detail. For the time being, we may say that it is a reflection of the negative liberalism about which we have spoken, which was also warned against by Newman.

Hence, Strossmayer maintains the following: "[H]appy are the people in which the men rule who, frequently confident of their weakness and defect through and through, prostrate themselves in their humility before the Holy Cross many times and search for and find the main fundament of science, sapience, excellence and proficiency of theirs in God and in the sacred religion" ("blago narodu u kom vladaju ljudi, koji o slabosti i nedostatku svom skroz na skroz uvjereni često i često puta se pred sveti križ u poniznosti svojoj prostru, te znanosti, mudrosti, izvrsnosti i vještini svojoj glavnu podlogu u Bogu i svetoj vjeri traže i nalaze"; qtd. in Kušar 75). This would actually signify that an Authority is miserable, that the laws are impotent, and that a public administration 
is a mess without a real and vivid Christianity, so Strossmayer opines that "it is as plain as day how much the Holy Church should be thanked to as regards the public life, a public eudaimonia” (“jasno kao dan koliko se svetoj Crkvi, gledano na javni život, na javnu dobrobit, treba zahvaliti”; qtd. in Kušar 75). Primarily for that reason, it is important that mutual love, concord, and peace are present between the State and the Church.

It is obvious, viz., that if the State is from God,

if its essential mission is to extend and protect truth and justice, and consequently all the felicity in this world, via its system, occupation, and activity, if none, neither an individual nor the state, can fulfill that sacred mission without Christianity, then, in each step and public endeavor, the state is referred to the love, accord, and peace with the Church of God, because the Church is also directly from God and because its marvelous and exemplary system is the greatest gift that God could have given to the humankind and commend it to the human heart; for it executes the same mission for all mankind, and in an equivalent way, that Jesus Christ had undertaken in this world and on the wood of the Cross, which was to consecrate, exalt, and direct all the relations ... toward a higher purpose of this world and of the hereafter by the light, grace, truth and life of God. (Kušar 103)

ako joj [državi] je bitna zadaća da sustavom, zvanjem i djelovanjem svojim istinu i pravdu, a po tomu i svaku sreću na ovom svijetu širi i čuva, ako toj svetoj svojoj zadaći bez kršćanstva nitko niti pojedinac niti država ijedna zadovoljiti ne može, onda je država svakim svojim korakom i javnim poduzećem na ljubav, slogu i mir sa Crkvom Božjom upućena, jer je i Crkva neposredno od Boga i jer je njezin divan i uzoran sustav najveći dar, koji je Bog rodu ljudskom pokloniti i srcu čovječjem preporučiti mogao: jer ona onu istu zadaću i onim istim načinom u čovječanstvu vrši, koju je Isus Krist na ovom svijetu i na drvetu križa vršio, a ta je da je svjetlom, milošću, istinom i životom Božjim sve odnose . . posveti, uzvisi i na višu svrhu ovoga i onoga svijeta uputi.

For Newman, it was of course also of an exceptional importance to correctly understand the relationship between the Church, society, and the State. The mode in which that relationship functioned in the Anglican Church was not appealing, and we may say at liberty that it was exactly a dissatisfaction by this 
relationship between the Church and the State that was one of the main reasons because of which Newman abandoned the Anglican Church. We will only mention an attempt to establish an Anglican diocese in Jerusalem together with the Protestant Prussia, in which the Anglican Church took part. Newman grasped it as a pure political move, raising a question of whether that Church serves to the State or to God (A. W. Hu. 517-20; Meyer 6: 138). In the work Apologia pro Vita Sua, Newman writes of the event that it was "the beginning of the end" (146), in the sense that he "set his mind" hereby and decided to slowly leave the "safe nest" of his Anglican Church. A pathway of Newman's transition to the Catholic Church was in fact that of conscience, not of subjectivity that is to be proven but rather of obedience in respect of the truth that has been revealed to him step by step, and the veracity of the relationship between the Church and the State and his deliberations are very close to those aired by Strossmayer on what that relationship should be.

\section{The Church, the State, and the Right to Religious Liberty Today}

Observed from a present-day perspective, Newman's and Strossmayer's vision of the relationship between the Church and the State, especially an emphasis on the comprehension of concord as an imperative, may seem to some a new utopia, something ultimately imaginary. Nevertheless, the problems in the relationship of the Catholic Church and the State today, as well as in their time, are not in the fact that the apprehension and concord between the Church and the State are something that is unrealistic, utopian, but exactly due to the fact that the lies and inconsistencies have caused that radical separation. A modern liberal State cannot be blamed for that solely, as the individuals within the Church are quite certainly responsible for it, too. Thus, there have recently been many debates related to the topic of the relationship between the Church and the State, with a desire to find out an optimal model.

So, the contemporary philosophy speaks about a multitude of theoretical models in the Church - State relationship. Eventually, we will see that an optimal model reached by the present-day theoreticians rests on the principles findable exactly in Newman and Strossmayer (Živić and Šokčević 22-23) that classifies the two of them in the line of authors for whom we may freely say that they have had a vision of that relationship, which was entirely ahead of their time because it guarantees a religious liberty by itself. Also, when we observe it through history, it is worth mentioning that it is difficult to say that, at the 
present time, any State functions strictly pursuant to the delineated positions, but one should speak about different positions that certain countries have taken throughout history when it comes to that relationship. The scope of these positions is diverse and encompasses several models about which many authors have debated, of which we would especially emphasize the contributions by Francis Russell Hittinger (39-55) and William Cole Durham, Jr. (1-44).

Accordingly, in a description of the religion (Church) - State relationship model, Durham starts from a positive identification of religion and the State and combines the lowest level of religious liberty with the theocratic régimes, dominant in the Islamic countries nowadays, where that level depends on how flexible an interpretation of the Shari'a law is. A greater degree of religious liberty is vouched by the model of the so-called "national or state religions," whose scope of activity may be expanded from monopoly to tolerance, depending how a régime treats the minorities (Durham 20). On the level of that model, religious liberty is at a higher degree than in the theocratic régimes, especially if the segment of tolerance is cherished, but if it comes to monopoly, that degree is still very low.

Nonetheless, on the example of the Anglican Church, Newman has demonstrated very evidently that this model is not exactly the best one either for the Church or for the State. The next model on the religious liberty scale is a model of the religion (Church) that holds a particular meaning for the nation, i.e., of "one particular church [that] has a special place in the country's traditions" (Durham 20). That model respects all the identificatory characteristics of certain folk, which in this case are the religious ones and which have become a historical heritage of the nation. With such a model, the rights are declaratively guaranteed to the religious minorities, but there is always a possibility to privilege the dominant Church. It is worth emphasizing that a partial identification of the Church (religion) and of the State is present in that context, which means that the model also respects the fundamental secular principle of separation of the Church from the State, be it on the very realistic bases, while appreciating the heartbeat of the folk and of the nation. Another step in the realization of religious liberty is provided by the models of collaboration, enforced by the contracts, arrangements, and concordats. Such models secure finances for the Church while taking care not to favor either of the religious options and to guarantee equal rights to all. Naturally, certain difficulties in practice may exist even 
here (since various religious communities have different needs, and it is occasionally problematic to comply with all requirements).

For the sake of clarity, one should stress that the previous three models (national, state religions; the religions that hold a particular meaning for the nation, and the cooperation forms between the Church and the State) may actually assure quite a satisfactory religious liberty degree, since the State respects the identificatory characteristics of a nation, folk, and its citizens, especially within the previous two models, and by the affixation of signatures to the contracts it is raised to an even higher level, as this partial identification assumes its legal force and a warranty that the right to religious liberty will indeed be respected. Additionally, the basic principles of secularity and laicality are satisfied, for the identification is not complete, like in the case of theocratic régimes, but a partial one, denoting that both the Church and the State have their separate fields of activity and specific competences.

Meanwhile, the theoreticians speak about yet another model that represents an ideal and guarantees the greatest religious liberty, and one of the key elements of the model, according to Hittinger, is a "proactive concord," which is actually very similar to what is asserted by Strossmayer and Newman (50). That model may be considered a collaboration. Hereby, there is an awareness about the existence of certain fundamental moral convictions that comprise a "moral identity," and they are not the mere preferences, but are an optio fundamentalis to the people. A "proactive concord" insists upon the separation of the Church from the State, but it retains a benevolent neutrality toward religion. We speak about a "benevolent" neutrality here, since there is a direct danger, observed by the Canadian philosopher Charles Taylor (17-25), consisting of the fact that a laical State, in a struggle for its neutrality toward the religious convictions, is transformed in "a state that is principally against religion and which actually supports the secular convictions" ("državu koja je načelno protiv religije i koja zapravo podržava sekularna uvjerenja”; Raguž, "Laička" [2013] 692). In other words, it may act according to the principles of negative liberalism we have discussed previously. For a "proactive concord," propensity and respect are also very significant, which is in the spirit of what Pope Pius XII and Pope Emeritus Benedict XVI call a "salubrious secularity", as findable in the more meticulous analyses of the relationship between the Church and the State in the thoughts of Charles Taylor and Pope Emeritus Benedict XVI, conducted by the theologist Ivica Raguž ("Papa” 334-53; "Laička” 354-69). 
A State that assures the "proactive concord" and neutrality is not only in line with Newman's and Strossmayer's ides, but is, in our opinion, also in line with Aristotle and Georg W. F. Hegel, and its sense is not exclusively comprised of the assurance of peace, social security, fundamental equality before the law and the elimination of obstacles obstructing a free personal life (negative liberty), but is also comprised of the creation of positive opportunities for the development of people as spiritual beings (positive liberty). The objective of that liberty is selfrealization. Anton Stres emphasizes that thereby "a wide spectrum of spiritual possibilities" is open to a human being, "as well as a possibility not to opt for any of them" ("široka lepeza duhovnih mogućnosti” . . . "ali i mogućnost da se ne opredijeli niti za jednu od njih"; 77). However, the State cannot be indifferent to whether the citizens will accept or reject the opportunities it offers to them, whether they will accomplish themselves as free and moral beings who search for the good and the truth, or whether they will become slaves of private, particular, instinctive aspirations, i.e., whether they will live a rich spiritual life or whether they will exist spiritually empty. Hereby, we arrive to what is underscored by Strossmayer, too, when he points out that it is significant that the State Authority incumbents are humble as well and that they embrace the truth in a certain way. Of course, the State is not amenable in relation to which spiritual and moral standpoints should be realized, and that is why the separation of the Church from the State (non-identification) is important. Still, it does not imply a radical opposition, but rather respect and collaboration.

Besides, it is important to understand (and repeatedly stress) that the European society is permeated by Christianity, and any form of neglection of Christianity and of the repudiation of its significance is an immense historical and civilizational injustice, about which Newman also wrote (Šokčević, Filozofija 46). Ergo, if the concordats, i.e., the compacts between a national government and a religious group, are concluded with the Catholic Church, if religious education is financed, if a religion is recognized with a special significance, a basic principle of righteousness is actually respected, being thereby essentially incorporated in an ideal model of the Church - State relationship already bespoken by the aforementioned philosophers of the law. What is more, as we may see on the example of numerous European countries, a "proactive concord" and neutrality are also realistically realizable within such models. Correspondingly, we are of the view that the European countries may inherit and incorporate the "proactive concord" and neutrality templates and thereby achieve a very high degree of religious liberty for their citizens. 
We are of the opinion that a radical and uncompromising separation of the Church and the State ensues from a sphere opposite to the aforementioned positive identification, i.e., from a negative one, for which we would say that it emanates from a negative form of liberalism that is still present today. In that respect, we nowadays speak about the models of legal or bureaucratic insensibility, which even does not have to possess an antireligious charge, since such regulations usually do not even harbor an awareness that they have certain religious implications in themselves. Therefore, that form is called an "inadvertent insensitivity" (Durham 22). It does have a negative impact on religious liberty but certainly not to the extent to which it is influenced by secularism.

Incidentally, it pertains to a seriously infringed neutrality and to a strict separation of the Church from the State, whereby all that has been tried to be avoided by a "proactive concord" is being recrudescent. As a manifestation thereof, we have a fact that the ruling classes arrogate the State; promote atheism, agnosticism, and religious indifference; observe the State as being the fundament of a person, not a person as being the fundament of the State; and they finally do not respect that each person inherits or searches for his or her portion of the optio fundamentalis, thus depriving the nations of their spiritual and human exuberances, which eventually inhibits the development of the entire society. In the end, we have hostility and persecution. It is manifested in a way that the land and assets are expropriated from those who act according to the religious convictions. This is indeed not so pronounced in secularism, but it has been visible in communism in a special way, which is still present in certain parts of the world (Durham 23).

In this context, we opine that it is especially important to emphasize that an optimal model of the religion (Church) - State relationship should respect conscience, what is mentioned by Newman and Strossmayer as well. A religious liberty is founded on the liberty of conscience, and conscience is to be comprehended in all its connotations. So, speaking about conscience, Joseph Cardinal Ratzinger notes, to a greater part on the trail of Newman, that a human has to constantly bear in mind an ontological phenomenon of the notion of conscience, and it relates to a fact that something like remembrance, an anamnesis of the good and the true, is inserted in us, i.e., there is an internal proclivity of the human being to God (32). It is an internal sense, i.e., a capacity of recognition, to which it is important that a human being is open, since the closure and oppression to this anamnesis of being may cause abusive convictions (Ratzinger 
32). A human being is guilty of this neglection of one's own being, by which an oppression of the being's anamnesis is blasphemed, for these acts rendered the human being obtuse to the voice of the truth in its inner person. Such a human being follows the dominant thoughts (frequently also the utopian ones), thus eliminating the truth from one's own life. A manifestation thereof is visible in the various forms of ideologies of the past centuries and of these days, too.

In our judgment, one of the reasons for such an elimination of the truth can be searched for in the fact that the citizens (irrespective of a religious persuasion) unreflexively accept certain illusions, deceptions, and utopias through the conscious or unconscious neglection of an ontological dimension of their own being that has rendered them obtuse to the voice of truth and for its discourse in their inner person, and that has a deleterious impact on their religious liberty. Though there are no turn-key solutions to this problem, for a return to the right path, we would agree with Joseph Cardinal Ratzinger (69), it is necessary to pray together with the psalmist: "And from pride preserve your servant, never let it be my master. So shall I be above reproach, free from grave sin" (Ps. 19.13). However, we think that it is significant to also take a theological-philosophical pathway and try to comprehend the reasons for conscience suppression through a critical, commonsense excogitation, in addition to this spiritual challenge. It is known, viz., that the consequences of conscience suppression may be catastrophical on a personal level. Primarily, it is due to the fact that such a person lives in a lie constantly, unauthentically, inconsistently, and is, in other words, neither in God nor in the truth. Such a person destroys himself or herself, for a life in lie prevents self-actualization and self-realization while also destroying the lives of other people close to it. Thereby, the edification of a true unity in love is obstructed, which is reflected on the very society and the State, too, which, as we have seen, exactly necessitate scrupulous citizens.

\section{Repaganization}

To our judgment, the main reason for decadency, a fall from collaboration and concord between the Church and the State into secularism and a condition in which we currently have a lack of religious liberty, is equal to that in Newman's and Strossmayer's time, and it pertains to a negative type of liberalism, in which we recognize the forms of dystopia. It is explicitly visible that such liberalism prevents and suffocates the anamnesis of human essentiality and disturbs 
our right to a path toward the truth, i.e., it suffocates religious liberty and is a fundament of repaganization about which Strossmayer also spoke.

The theoreticians recognize this utopian mindset by the fact that, in it, there is always an aspiration to the ultimate solution to all problems, so that everything existent should be compatible to the desires of each person and that everything that creates confrontations and tensions should be eliminated. ${ }^{2}$ The second essential characteristic of that "utopian intellect" lies in the fact that it is based on an ideal immune to refutation, which can be neither realized nor denied. A utopist is capable of scrutinizing the solutions which were arrived at by common sense and experience. He or she is thus also capable of positioning the absurd projects in the center of cogitation because he or she does not consider these projects' absurdity a deficiency. Quite the reverse, he or she may actually lodge an objection against a person warning about such an irrationality. While so doing, a utopist may essentially rely on the acceptance of absurdity exclusively because of itself. ${ }^{3}$

The third utopists' characteristic is visible at the moment of their assumption of power, whereby the very instability of their objective, which is always beyond their reach, requires them to find a secret group or a conspiracy that prevents their realization. That group is usually presented in the public as the one below the human level, unjustly successful, or intrinsically worth punishing. ${ }^{4}$ Finally, we would also add the fourth characteristic, namely the suffocation of liberty (including religious liberty), manifested as a consequence of the previous three (Scruton 62-79; Šokčević, "Aberacije" 361-75).

Hence, a seductive force of the utopian lies in a promise of formal perfection that impeccably reconciliates "what it is" with "what it should be." This amalgamation of reality and of the valuable is in fact a form of corruption of internal connection between the ideas, motives, and values on the one hand and of a human activity and experience on the other. It is visible in numerous manifestations of a "utopian intellect," which is a cancer of liberal democracy demonstrated through the metastases whose list is not finite, and is certainly

2 E.g., in communism, the origin of all problems was private property, and there was an illusion that everything will be solved if the property becomes collective.

$3 \quad$ E.g., all the education reformers speak about a "knowledge society," but if we observe it a little bit more profoundly, we see that it relates to a pure dystopia. This syntagm is a part of a utopia that education will bring felicity to the humankind and that it is always necessary to reform something.

4 E.g., the Nazis selected the Jews, the Russian Communists had the kulaks, and the targeted group today are the Catholics. 
complementable by the always new, emerging deviations. These deviations are a path toward repaganization, which practically leads to the dechristianization of the Western world. It is especially observable in the emergence of the New Age as a sort of celebration of the self, through which the people become the epistemological individualists, and that form of religiosity relies on the mindset of a postmodern human being, to whom humanism without God is a principal life weltanschauung. The atomistic human cult implemented by liberalism, consisting of the eradication of a human's moral substance and the sacrifice of his or her internal liberty to the fetish of an unlimited power, as stressed by the Hungarian philosopher Aurel T. Kolnai, is also of benefit to it (272-335). This is exactly an attempt of a modern human being to become a master and an owner of nature and to surmount a contingency of his or her own that limits him or her essentially. Its goal is a destruction of all objectivizations, the religious, philosophical, legal, and social ones that leads a human being to nihilism. The mode in which this totalitarianism format acts is considerably more insidious than that of Nazism and communism, for it dexterously finds the mechanisms that facilitate it to be successfully hidden under a disguise of liberalism and tolerance (Kolnai 272-335).

Repaganization is also visible in an increasingly extreme capitalism, which, according to the German philosopher Walter B. S. Benjamin, has become a pure cultus, a paganic pantheistical religion without dogmata and without theology, for it recognizes only financial transactions and commodities and services exchange (288-91). It does not allow for the existence of other, veracious religion next to itself, it cherishes the permanency of cultus continuously (whereby we think of a consumeristic cultus of usance), and it supports a cultus of borrowing, in which we have a permanent sacrifice for the sins instead of a remission of sins, as was the case in the paganic religions. Furthermore, observed generally, capitalism is based upon a utopia of societal progress and a conviction that the expansion of markets and the growth of international companies is something that has no alternative and is evolutionally necessary (Tanjić 75-83; Matulić 312-14).

Within repaganization, we may say that a "utopian intellect" is very close to Gnosticism, whereby we think of a tendency to enter into the transcendental directly in our reality and of a demand that the ultimate end of the world should come here and now (as the establishment of the kingdom of the heavens on earth). A human is reduced to the gnosis - to the knowledge in which he or she finds the salvation. Pope Francis sees such an influence of Gnosticism in the 
so-called "secular spirituality" as well, which is actually a form of an anthropocentric immanentism. The intellect, as a locale of knowledge production, is exclusively construed as an instrumental, mercantile, and calculatory entity. There is no place for love as a form of knowledge and the relational weltanschauung method, which becomes a common conscience in time. Due to Gnosticism, the present-day human being is unidimensional, an expert and a specialist in his or her domain but closed to the entire reality. This is also reflected on that person's culture, but it suffocates religious liberty, too, as we have seen. A person who is not open to the integrity of reality, to the truth as a whole, is actually a sophist, a relativist who does not need the normative fixtures in his or her life, even in culture. We may say that without standardization, culture, and education plunge into crisis. Friedrich W. Nietzsche once articulated that "[w]e possess art lest we perish from truth" (435). Exactly, it is imposed as a clear thesis per se that the more humane a culture is, the more open it should be to the truth; nevertheless, the present culture of kitsch and spectacle appears distant from the truth.

Since, in their deliberations, Newman and Strossmayer are very close to the analyses of a global crisis findable in the quoted contemporary authors, we are of the opinion that its solution should be searched for according to the same method they had proposed-in education. We consider that to be a good way, and we do not hold it to be a platitude frequently encountered in modern politics, where all the possible problems are illusively desired to be solved by education. We think that there is a problem in education as perceived by the current political élites. The contemporary educational institutions, namely, privilege precisely those who reject the old values, hierarchy, and the old forms of social order. Thus, in the domain of hodiernal culture, "anything goes" and nothing goes at all. Roger V. Scruton emphasizes that "one of the greatest superstitions of our time relates to the fact that education should be for the benefit of those who receive it" (29). Therefore, we always ask ourselves in schools and in colleges what the students get from what we instruct them about and whether it is relevant in the sense of its connection with their interests. This is the cause of all errors of educational systems, and it is obvious that many educate the people's masses, but these masses know little or nothing. A true teacher loves his or her student, but he or she especially loves knowledge that should be transferred to the student, since the transfer of knowledge is an objective that must not be downplayed by any means.

Particularly, the question is frequently being asked of why a child should know William Shakespeare, listen to Johann S. Bach, and develop an interest in 
the Latin language, or what catechism is for. The response is clear. The teachers and professors transfer a culture not to bring a direct benefit to an individual but to contribute to the human species while preserving a form of knowledge that would otherwise vanish from the present-day world (Scruton 30). That form of knowledge, we would say, is not a doctrinaire one, which confines a person, but a knowledge open to the integrity of the being, a knowledge that searches for the truth that resides in any human being in his or her nature. Strossmayer and Newman also spoke of that knowledge dimension.

A student who is a part of the educational process in which there is no objective is normatively compelled to create his or her own opinions in the same way he or she styles his or her hair in the morning before going to school. Thus, he or she does so not pursuant to the criteria of the truth but according to what is fashionable and what is enforced by the so-called "political correctness" and the omnipresent media. Liberty has consequently been reduced to the personal desires, interests, and preferences, so Tonči Matulić is right when he emphasizes that the basic moral law of nowadays is actually present in emotivism, founded on a fact that a person should act according to his or her emotions (611-16). The modern education reformers abhor, on behalf of the so-called "love for the students," any form of a traditional idea of education and will not stop doing it, for there is no more merciless antipathy than a hatred out of love.

Finally, as the illusions, delusions, and mendacities are present in the quintessence of a "utopian intellect," so we also see the identical phenomena in the center of its principal metastasis, repaganization, and in its numerous trends. It should not surprise us, as the mendacities, illusions, and utopias are the favorable instruments of all totalitarianisms. A lie, as underscored by the German philosopher Josef Pieper, precludes communication, because to lie means to deprive a counterparty of reality, i.e., of the participation in reality, thus instrumentalizing it for some proper ideas or goals (33-35).

\section{Conclusive Thoughts}

Catholicism may be, and has to be, an alternative to the primacy of liberalism and its metastases primarily because it is realistic, so that the hereafter is clearly distinguished from the earthly, which the secularized theories are incapable of doing. However, we are of an opinion that the human species still likes the inspiring fantasies more than the disillusioning facts. In the apostolic exhor- 
tation Evangelii gaudium, Pope Francis, probably for that reason, also appeals to the fact that the reality is more important than the ideas, i.e., it must not occur that the idea loses contact with the reality, with the common sense, as we would phrase it, and this is exactly what happens to a "utopian intellect" (231-33).

Therefore, we deem the real Church, which transforms the ideas and the Word of God into the acts of justice and love in life, to be the only veritable opposition to the action of a "utopian intellect." Such a life is connected to the faith in a special way, and this is particularly important if we know that Christianity, in its long history, has more frequently been imperiled by the infidelity of its believers than by some external factors. In this case of liberalism, it means that an emphasis should not be put on iniquity and immorality all the time, like the veterotestamentary prophets did. We think that a reflection of contemporary problems, which we have provided in the last chapter, is necessary, for we have referred hereby to some causes that impede our path toward the truth; yet it holds no value to despair over that right now, but we should contemplate what to do primarily from the perspective of the Catholic Church to place the malady under control and progress toward curation. In that sense, from this analysis of Strossmayer's and Newman's comprehension of the relationship between the Church and the State, we note several crucial directives for the Catholic Church so as to preserve that potential of the faithful. We consider that all these directives should be accompanied by a neotestamentary logic of love and liberty that lead to the truth.

This logic should be implanted into a "proactive concord" and collaboration between the Church and the State, which is additionally enhanced by the fact that the idea of a modern laical State ultimately has Christian roots as well. Therefore, we are of an opinion that it is necessary for the Church to endorse the models of how to preserve the potential of the faithful that it has, to raise their awareness, to educate them, and direct them to the truth and to a greater religious liberty so as to ensure that this potential of the faithful does not evanesce and fall under the influence of a "utopian intellect," i.e., of negative liberalism.

In addition to the aforementioned dimension of education, greatly under the impact of Newman and Strossmayer, it is significant, in order to prevent the evanescence of the potential of the faithful from happening, that the Church should foster the building of a liberal society beyond any totalitarianism and that it should underline the development of solidarity in the sense of an involvement in the lives of others, in their fundamental moral convictions, which is the 
essence of pluralism. The ideas of some of the contemporary philosophers are headed that way (Žalec 85-100).

However, that alone is not sufficient. In our view, in the connection of a liberal democracy with the metastases of a "utopian intellect," courage is a crucial virtue for the formation of that potential, particularly the courage pertaining to our correct comprehension of God. Indeed, that second courage, of which Paul J. Tillich speaks, is focused on the fact that the ultimate origin of our courage is "God of the God of theism," who is the object of all mystical anticipations and who exceeds any objectivization of God (186-90).

In addition to courage, creativity is also required on the Old Continent in an effort to render Catholicism more attractive, because it has turned away from its origins and has assumed the paganic attributes due to an auto-victimization and an oikophobic, postmodern identity deconstruction. For such a regained attractivity, liberty and time are necessary, so Pope Francis rightly warns that the time is more important than the space (222-25). One should work slowly and in the long run and should not depend on the results, since this dependence is a feature of Gnostic "secular spirituality." A human being is not redeemed by scientific results, although knowledge, indeed, is a form of power, as accentuated by Sir Francis Bacon in 1597 in his Meditationes Sacree (Spedding 79), ${ }^{5}$ but the real power arises from love, from the assistance to a concrete human being (person), which mutually redeems (a renderer and a recipient) and returns to the status of liberty. What is also needed by a human being is hope; nonetheless, the hope a human being searches for is not merely a naïve optimism, a utopia disassociated from reality, but a utopia that is founded on the realistic ${ }^{6}$ and is related to all to which we should aspire, to the complete reality, to God. Yet, it would be realistically possible to repeatedly recall the fact that the Church's primary objective in the world is not to just exist in it, but, as underlined by Newman, to really take care of the salvation of the souls (qtd. in Rowlands 198). On the thirty-sixth page of the seventh volume of his Parochial and Plain Sermons, published in London by Longmans, Green in 1907, Newman writes as follows:

[T] he Church so far from being literally, and in fact, separate from the wicked world, is within it. The Church is a body, gathered together in the

The exact expression reads “ipsa scientia potestas est”: 'knowledge itself is power.'

For Karl Rahner's argument about a "dynamic relationship" between utopia and reality, see Doyle and Walsh 362. 
world, and in a process of separation from it. The world's power, alas! is over the Church, because the Church has gone forth into the world to save the world. All Christians are in the world, and of the world, so far as sin still has dominion over them; and "not even the best of us is clean every whit from sin. Though then, in our idea of the two, and in their principles, and in their future prospects, the Church is one thing, and the world is another, yet in present matter of fact, the Church is of the world, not separate from it." (qtd. in Rowlands 198)

Along these lines, John H. L. Rowlands would say that the assignment of the Church is not to reform the society but to lead the humankind toward the salvation of the souls (193). The salvation of the souls, as a Church assignment, will lead toward the redemption of the humankind through sanctity. Therefore, the Church will always have a detachment from societal reforms, for they are frequently the transformations for the sake of changes. A reform, an alteration the Church should advocate, is actually the one bespoken by Newman, and that is a modification of the heart, a pathway to sanctity. The Church should always prioritize the spiritual, then focus on the temporal. It is clear, namely, that societal reforms cannot procure eternal felicity for a human being. Only a complete modification of the heart is able to exert a level of influence, because of which a human being can be redeemed. Yet, like in the 19th century, the reformers are presently also more attractive than the saints, for they desire to improve the human societal opportunities and expand a human being's knowledge based upon a logical, formal apprehension. However, the problem is that such an apprehension does not reach the crux-the human soul. The reformers cannot assist a human being to save his or her soul. That can only be done by the sacred personalities, whom we would recognize by the fact that they are the pacific, unpretentious, unobtrusive, humble and, above all, simple people, unlike reformers.

Therefore, it is more efficacious for Newman to be a soldier of Christ than a societal reformer (Rowlands 199-200). A sacred personality is also featured by the datum that, therein, the profoundest stadium of the intellect transcends the mere rationalization and orients itself to the intuition. For Newman, the faith is the reasoning of a divinely enlightened mind. It is an act of the entire human being, not only of his or her rational potencies. According to Newman, the State, and notably the Church, should aspire to a righteous condition of its believers' heart (qtd. in Rowlands 211). 
Thus, we may conclude that the issue of the relationship between the Church and the State is in fact a point of correct anthropology: for Newman, a salubrious relationship between the Church and the State is possible where a human being is approached as a complete individual, for it is the only method to preserve consistency, authenticity, and the verity of human existence in a religious and a social sense. Particularly, a human being exceeds any political option, for the politics and the State are here on account of the human, whereas the human is not here on account of the politics or of the State. Also, the Church should principally be devoted to its own mission of testifying to the Word of God and to the nurturing of conscience in a temporal order. Hereby, we arrive at something that is exceptionally significant to both Strossmayer and Newman, and that is the life of a person according to the dictate of conscience and the fact that one should be realistic and profoundly cognizant of numerous omissions that the people within the Church have made in history and cognizant of numerous omissions that the people within the Church still make today.

A cognizance thereof and repentance are actually especially important, for they manifest how vital the truth is to the Catholic Church, so Newman regrets, in the Letter to the Duke of Norfolk, the gravity of Gladstone's words while emphasizing that, according to him, there is nothing controversial in someone being a docile Catholic and a docile Englishman (Newman and Gladstone 78). According to Newman, that regret could primarily be provoked because our conscience seeks the truth, and the Catholic Church instructs and defends the truth. Nevertheless, we would say that these are the usual adversities the Catholic Church still encounters today, when acting publicly.

Finally, we deem especially momentous to accentuate that a religious liberty is founded on the liberty of conscience, and therefore a respect of the individuals' conscience is necessary for a salubrious relationship between the Church and the State, because this is a path toward the truth. To be successful therein, it is vital to follow the aforementioned neotestamentary logic of love, in whose fundaments the logic of incarnation is based. It subsumes the possession of a pure heart which is capable of loving the people, since this is the only way that we may hope to be able to build, upon consistent ethical values of Christian humanism, an authentic, humane liberal-democratic society of free people, which was advocated by Newman and Strossmayer during their entire lifetimes, and the reason they may be the intellectual, spiritual, and moral paragons to us in this connection. 


\section{Works Cited}

A. W. Hu. (Arthur Wollaston Hutton). "Newman, John Henry." Volume XIX: Mun to Oddfellows, edited by Walter A. Phillips, pp. 517-20. Encyclopoedia Britannica: A Dictionary of Arts, Sciences, Literature and General Information, general editor, Hugh Chisholm, 11th ed., vol. 19, Cambridge UP, 1911. 29 vols.

Benjamin, Walter B. S. “Capitalism as Religion." Selected Writings. 1913-26. Edited by Marcus Bullock and Michael W. Jennings, vol. 1, Harvard UP, 1996, pp. 288-91.

Čečatka, Antun. Viđenje Crkve J. J. Strossmayera (18015. - 1905.): Perspektive jedinstva sa slavenskim pravoslavnim crkvama. Teologija u Đakovu, 2001. Biblioteka Diacovensia: Studije 1.

Doyle, D[ennis] M., and C[had] Walsh. "Utopia and Utopianism.” New Catholic Encyclopedia: Second Edition: 14: Thi-Zwi, edited by Berard L. Marthaler, pp. 359-62. New Catholic Encyclopedia, general editor, Berard L. Marthaler, 2nd ed., vol. 14, Thomson Gale / Catholic University of America, 2003. 15 vols.

Durham, William C., Jr. "Perspectives of Religious Liberty: A Comparative Framework," Religious Human Rights in Global Perspective: Legal Perspectives, edited by Johan D. van der Vyver and John Witte, vol. 2, Nijhoff, 1996, pp. 1-44. 2 vols.

Hittinger, Francis R. "Political Pluralism and Religious Liberty: The Teaching of Dignitatis Humanoe," Universal Rights in a World of Diversity: The Case of Religious Freedom, edited by Mary A. Glendon and Harry Zacher, Pontifical Academy of Social Sciences, 2012, pp. 39-55.

Kolnai, Aurel T. “The Meaning of the 'Common Man.” The Thomist: A Speculative Quarterly Review, vol. 12, no. 3, Jul. 1949, pp. 272-335.

Kušar, Stjepan. "Inkarnacija, tolerancija i djelovanje Crkve." Liberalizam i katolicizam u Hrvatskoj: Zbornik radova sa skupa održanog od 2. do 4. lipnja 1998. u Splitu, u Vili Dalmacija, edited by Hans-Georg Fleck, vol. 2, Friedrich Naumann Stiftung, 1999, pp. 295-332.

Matulić, Tonči. Metamorfoze kulture: Teološko prepoznavanje znakova vremena u ozračju znanstveno-tehničke civilizacije. Glas Koncila, 2009.

Meyer, Philipp. "Jerusalem, Anglican-German Bishopric in." 1914. Volume VI: InnocentsLiudger, edited by Charles C. Sherman, p. 138. The New Schaff-Herzog Encyclopedia of Religious Knowledge, general editor, Samuel M. Jackson, vol. 6, Baker Book House, 1953. 13 vols.

The New Jerusalem Bible: Reader's Edition: The Complete Text of the Ancient Canon of the Scriptures. Doubleday, 1990.

Newman, John H. Apologia pro Vita Sua. J. M. Dent and Sons, 1912.

Newman, John H., and William E. Gladstone. Newman and Gladstone: The Vatican Decrees, Notre Dame UP, 1962.

Nietzsche, Friedrich W. The Will to Power. 1888. Edited and translated by Walter Kaufmann and Reginald J. Hollingdale, Random House, 1967.

122 Pieper, Josef. Mißbrauch der Sprache - Mißbrauch der Macht. Schwabenverlag, 1988. 
Pope Francis (Jorge Mario Bergoglio). Evangelii gaudium: Radost evanđelja: Apostolska pobudnica biskupima, prezbiterima i dakonima, posvećenim osobama i svim vjernicima laicima o naviještanju evanđelja u današnjem svijetu. Kršćanska sadašnjost, 2013.

Raguž, Ivica. "Laička država i sloboda vjerovanja danas: Teološki osvrt na doprinos Charlesa Taylora." Diacovensia: Teološki prilozi, vol. 21, no. 4, 2013, pp. 691-704.

---. "Laička država i sloboda vjerovanja danas: Teološki osvrt na doprinos Charlesa Taylora." Teološki fragmenti, vol. 3, 2017, pp. 354-69.

---. "Papa Benedikt XVI. o Crkvi, državi i politici." Teološki fragmenti, vol. 3, 2017, pp. 334-53.

Ratzinger, Joseph. On Conscience: Two Essays. National Catholic Bioethics Center / Ignatius Press, 2007. Bioethics and Culture Series.

Rowlands, John H. L. Church, State and Society: The Attitudes of John Keble, Richard Hurrell Froude, and John Henry Newman, 1827-1845. 1986. Durham U, master's thesis. Durham e-Theses, etheses.dur.ac.uk/6889/. Accessed on 17 Mar. 2021.

Scruton, Roger V. The Uses of Pessimism: And the Danger of False Hope. Oxford UP, 2010.

Spedding, James, et. al., editors. The Works of Francis Bacon, Baron of Verulam, Viscount St. Albans, and Lord High Chancellor of England, vol. 14, Brown and Taggard, 1861. 15 vols.

Stres, Anton. Sloboda i pravednost. Kršćanska sadašnjost, 2001.

Strossmayer, Josip J. Sve za vjeru i za domovinu, vol. 2, Nadbiskupski ordinarijat, 2015. 4 vols.

Šagi, Bono Z. Izazovi otvorenih vrata. Kršćanska sadašnjost, 1993.

Šokčević, Šimo. "Aberacije 'utopijskog uma' i hrabrost filozofiranja." Filozofska istraživanja, vol. 34, no. 3, Jan. 2015, pp. 361-75.

---. Filozofija obrazovanja Johna Henryja Newmana. Biblioteka Diacovensia, 2017.

Tanjić, Željko. Teologija pred izazovima sadašnjeg trenutka. Kršćanska sadašnjost, 2009.

Taylor, Charles. “The Church Speaks-To Whom?” Church and People: Disjunctions in a Secular Age: Christian Philosophical Studies, Volume I, edited by Taylor et al., pp. 17-25. Cultural Heritage and Contemporary Change: Series VIII, general editor, George F. McLean, vol. 1, Council for Research in Values and Philosophy, 2012.

Tillich, Paul J. The Courage to Be. Yale UP, 1952.

Žalec, Bojan. "Religija, demokracija i solidarni personalizam: na putu ka svjetskoj kulturi i civilizaciji.” Filozofska istraživanja, vol. 31, no. 1, Jul. 2011, pp. 85-100.

Živić, Tihomir, and Šimo Šokčević. "Strossmayerana in the English Sources: Acton, Gladstone, Newman and Strossmayer." Diacovensia: Teološki prilozi, vol. 26, no. 1, 2018, pp. 11-26. 


\section{NEWMAN I STROSSMAYER O ODNOSU IZMEĐU CRKVE I DRŽAVE (II)}

Sažetak
Šimo ŠOKČEVIĆ
Katolički bogoslovni fakultet u Đakovu
Sveučilišta Josipa Jurja Strossmayera u Osijeku
Petra Preradovića 17
HR - 31 400 Đakovo
simo.sokcevic@djkbf.hr
Tihomir ŽıIV́c
Fakultet agrobiotehničkih znanosti Osijek
Sveučilišta Josipa Jurja Strossmayera u Osijeku
Vladimira Preloga 1
HR - 31 000 Osijek
tihomir.zivic@fazos.hr

Suradnja Katoličke Crkve i države nužnost je i imperativ kojim su se bavili i John Henry Newman i Josip Juraj Strossmayer, važni mislioci 19. stoljeća, a modeli koji zapravo slijede njihova promišljanja postoje i danas. $U$ drugome dijelu tekstološke i teološke analize Newmanova i Strossmayerova shvaćanja odnosa između Crkve i države naš je cilj istražiti koliko Newmanova i Strossmayerova promišljanja mogu biti korisna pri oblikovanju osnova na kojima bi trebao biti izgrađen dobar odnos Katoličke Crkve i države. Vidjeli smo da su poimanje i sklad osnovni imperativi toga odnosa, kao i suvremenih modela koji ga analiziraju. Suvremene prepreke tomu odnosu imaju identične korijene, koji se nalaze u negativnome liberalizmu i repaganizaciji. Stoga na tragu Newmana i Strossmayera zaključujemo da je danas nužna antropološka reforma koja bi primarno zahvaćala ljudsko srce, ona koja mora shvatiti da je život u skladu s nečijom savješću, u istini, vrjedniji negoli sve utopijske laži i obmane koje tvore društvenogospodarstvene odnose i osobni život.

Ključne riječi: John Henry Newman, Josip Juraj Strossmayer, Katolička Crkva, odnos, antropološka reforma 